\title{
Effect of extender composition and storage temperatures on motility of preserved boar semen
}

\author{
L. Fraser, M. Lecewicz, R. Krasicki and J. Strzeżek \\ Warmia and Mazury University in Olsztyn. Faculty of Animal Bioengineering, \\ Departinent of Animal Biochemistry' \\ Oczapowskiego 5. 10-718 Olsatyn, Poland
}

(Received 27 May 2002; accepted 11 October 2002)

ABSTRACT

Ejaculates, collected over a 35-month period from 3 Polish Landrace boars from 8 months of age, were diluted $\left(30 \times 10^{6}\right.$ sperm/ $\left./ \mathrm{cm}^{3}\right)$ with a standard extender, Kortowo 3 (K3) supplemented witl lipoprotein fractions extracted from hen (K3-LPFh) or ostrich egg yolk (K3-LPFo). Thereafter, the diluted sperm samples were stored for 4 days (DO to D4) at $5^{\circ}$ and $16^{\circ} \mathrm{C}$, respectively. Irrespective of the extender composition and storage temperatures, sperm motility was gradually reduced during prolonged storage. The decline in sperm motility was more accentuated in $\mathrm{K} 3$ extender compared with LPF-based extenders. Seasonal influence was more apparent in K3-LPFo extender during storage at $5^{\circ} \mathrm{C}$.

The results of this study demonstrate that the inclusion of lipoprotein fractions in semen extender enhanced cold shock resistance of boar spermatozoa, particularly during storage at $5^{\circ} \mathrm{C}$.

KEY WORDS: boar, spermatozoa, motility, lipoprotein fractions, extender, temperature

\section{INTRODUCTION}

Liquid preservation is still the preferred method of storing boar semen. Many efforts have been made to improve boar semen extender quality, thus allowing storage at $17^{\circ} \mathrm{C}$ for more than 3 days (Weitze et al., 1991). The effective use of chilled semen for AI depends upon the ability of the extender to provide a suitable environment for spermatozoa during storage. Many extenders are formulated to enhance preservation capabilities by providing compounds to protect the spermatozoa against cold shock (Althouse et al., 1998). The fertility of stored boar semen is influenced mainly by the original semen quality, the number of spermatozoa 
per AI dose, and the composition of the media used for extension (Johnson et al., 1988; Waberski et al., 1994).

Sperm fertilizing ability is related to its metabolic performance. In this sense, motility is one of the parameters related to the metabolic ability of spermatozoa. Evaluation of the percentage of spermatozoa exhibiting progressive motility is the most commonly used indicator of both viability and fertility for boar semen, though a high level of motility does not guarantec better reproduction results (Kuster and Althouse, 1999; Fraser et al., 2002). Estimation of motility, therefore, has fundamental importance in the daily quality control of the semen. Furthermore, computer measurements of sperm motility parameters provide valid indicators of boar semen quality that can be related to fertility (Fraser et al., 2000). Regular motility checks after dilution and during the storage period give information concerning the longevity of the semen of each boar and of its individual peculiarities.

Extended boar semen is cooled to between $15^{\circ}$ and $18^{\circ} \mathrm{C}$ and is maintained at this temperature for several days until use for $\mathrm{Al}$. The temperature of semen storage is an important factor in retaining the fertilizing capacity of boar spermatozoa (Althouse et al., 1998). Paulenz et al. (2000) reported optimal results at $20^{\circ} \mathrm{C}$ and undesirable effects of storing boar sperm at $10^{\circ} \mathrm{C}$ in Beltsville Thawing Solution (BTS). The aim of this study was to investigate the effect of a standard extender supplemented with lipoprotein fractions extracted from hen (LPFh) or ostrich egg yolk (LPFo), and storage temperatures on motility of liquid boar semen.

\section{MATERIAL AND METHODS}

\section{Semen collections and assessment}

Over a 35-month period from February 1999 through December 2001, cjaculates were collected once weekly from 3 Polish Landrace boars from 8 months of age. All the boars were housed under the same conditions and were given a commercial pig ration. Water was available ad libitum. Semen was collected using the gloved-hand technique, and the gel portion was removed using double gauze.

The following parameters were evaluated on fresh, unextended boar semen: volume, sperm motility, sperm concentration, total abnormal sperm, and sperm plasma membrane integrity (viability). Sperm motility was analyzed by placing a sample on a pre-warmed microscopic slide overlaid with a coverslip. Total motility was estimated to the nearest $5 \%$ by viewing groups of sperm in at least $4-5$ different fields at $200 \mathrm{x}$ using a light microscope equipped with an attached heated stage $\left(37^{\circ} \mathrm{C}\right)$. Fresh, unextended ejaculates which had less than $70 \%$ were not included in the pool for that collection period. Sperm concentration was determined using a hacmocytometer. Sperm morphology was evaluated after making fresh semen 
smears on microscopic slides as described by Watson (1975). A DNA-specific fluorochrome, Hocchst 33258 (Calbiochem LA Jolla, CA, USA), was used to assess sperm plasma membrane integrity (Fraser et al., 2001).

\section{Semen storage}

The minimum values of fresh boar semen parameters are shown in Table 1. Following standard semen parameter evaluation, a total of 96 ejaculates was diluted with a standard extender, Kortowo 3 (K3), containing sodium citrate, fructose, EDTA, potassium acetate and gentamycin (Strzezek et al., 1998). The K3 extender was supplemented with lipoprotein fractions extracted from hen (K3-LPFh) or ostrich egg yolk (K3-LPFo). The extraction procedure of the lipoprotein fractions from hen or ostrich egg yolk has been described elsewhere (Demianowicz and Strzeżek, 1996; Strzeżek et al., 1999). Briefly, the egg yolk was separated from egg white and traces of albumin were removed by blotting it on filter paper. The yolk membrane was broken and the liquid yolk was used to prepare the lipoprotein fractions.

TABLE 1

Minimum values of fresh, unextended boar semen used for liquid storage

\begin{tabular}{ll}
\hline Semen parameters & Values \\
\hline Gel-free volume & $>200 \mathrm{~cm}^{3}$ \\
Total sperm motility & $>70 \%$ \\
Sperm concentration & $>0.5 \times 10^{\%} \mathrm{sperm} / \mathrm{cm}^{3}$ \\
Total sperm numbers & $>110 \times 10^{\prime} \mathrm{sperm} / \mathrm{cjaculate}$ \\
Total abnomal sperm & $<10 \%$ \\
Viability (membrane-intact spermatozoa) & $>85 \%$ \\
\hline
\end{tabular}

The semen samples were diluted with K3, K3-LPFh and K3-LPFo extenders to a final concentration of $30 \times 10^{6} \mathrm{sperm} / \mathrm{cm}^{3}$ and were dispersed into $100 \mathrm{ml}$ plastic bottles. The diluted semen was left to equilibrate for $2 \mathrm{~h}$ at room temperature, and was stored at $5^{\circ} \mathrm{C}$ (Refrigerator) and $16^{\circ} \mathrm{C}$ (Thermobox). The portions were gently agitated once daily to resuspend the spermatozoa. Motility analysis was conducted at $2 \mathrm{~h}$ after dilution (D0) and after every $24 \mathrm{~h}$ of storage (D1-D4).

Statistical analysis

All values obtained were expressed as mean \pm standard deviation (SD). In order to simplify presentation of the data, the ejaculates were divided into 2 age groups, 8-24 months and 25-42 months, and 2 seasonal periods, autumn-winter and springsummer. Student's t-test was used to compare parameters within the age groups and seasonal periods. Duncan's multiple comparison test was used to compare the means 
among the different extenders and among the storage periods. Calculations were carried out using the STATISTICA software package (STATISTICA for Windows, Stat Soft Incorporation, Tulsa $O K$ ). A value of $P \leq 0.05$ was chosen as an indication of statistical significance.

\section{RESULTS AND DISCUSSION}

Table 2 shows that the percentage of motile spermatozoa was higher $(P \leq 0.05)$ in K3-LPFh- extended semen of boars aged 25-42 months compared with that of $\mathrm{K} 3$-extended semen on D0 of storage. In addition, sperm stored in $\mathrm{K} 3$ extender exhibited lower $(\mathrm{P} \leq 0.05)$ motility than those stored in K3-LPFh extender during the spring-summer period.

TABLE 2

Motility (\%) of liquid boar semen following 2 h equilibration in K3 extender, supplemented with or without egg yolk lipoprotein (means \pm SD)

\begin{tabular}{|c|c|c|c|c|c|}
\hline \multirow{2}{*}{ Age/Season } & & \multirow{2}{*}{$\begin{array}{l}\text { No. of } \\
\text { ejaculates }\end{array}$} & \multicolumn{3}{|c|}{ Extended semen after $2 \mathrm{~h}$ cquilibration (D0) } \\
\hline & & & $\mathrm{K} 3$ & $\mathrm{~K} 3-\mathrm{LPFh}$ & K3-LPFo \\
\hline \multirow{3}{*}{$\begin{array}{l}\text { Age of boars, } \\
\text { montlss }\end{array}$} & & & & & $(13=-12)$ \\
\hline & $8-24$ & 56 & $70.4 \pm 4.4$ & $75.9 \pm 4.3$ & $70.0 \pm 5.0$ \\
\hline & $25-42$ & 40 & $69.9 \pm 5.2^{\prime}$ & $75.6 \pm 5.2^{\mathrm{h}}$ & $73.6+4.9^{1 \mathrm{t}}$ \\
\hline \multirow{4}{*}{ Scason } & & & & & $(n=27)$ \\
\hline & Autumn-Winter & 64 & $70.5 \pm 4.7$ & $75.6 \pm 4.9$ & $72.4 \pm 5.1$ \\
\hline & & & & & $(n=13)$ \\
\hline & Spring-Summer & 32 & $69.4 \pm 4.7^{4}$ & $76.2 \pm 4.1^{\mathrm{h}}$ & $72.9 \pm 5.4^{\mathrm{ib}}$ \\
\hline
\end{tabular}

values with different letters in the Some row are significant $(P<0.05)$

K3 - Kortowo 3 extender

K3 - LPFh - Kortowo 3 extender supplemented with lipoprotein fractions extracted from hen egg yolk

K3 - LPFo - Kortowo 3 extender supplemented with lipoprotein fractions extracted from ostrich egg yolk

Sperm cells progressively lost motility when stored in the supportive media at $5^{\circ}$ and $16^{\circ} \mathrm{C}$, regardless of the age of the boar and extender type (Table 3). The gradual decline in sperm motility was more pronounced in $\mathrm{K} 3$-extended semen compared with that of K3-LPFh- or K3-LPFo-extended semen. Sperm motility in extended semen of boars aged $25-42$ months was higher $(\mathrm{P} \leq 0.05)$ than that of boars aged 8-24 months on $\mathrm{D} 2$ of storage at $5^{\circ} \mathrm{C}$, regardless of the extender type. Individual differences among the boars on every day of storage were mainly noted with K3- 
extended semen, particularly at $5^{\circ} \mathrm{C}$. The proportion of motile sperm of either K3-LPFh or K3-LPFo extended semen did not statistically differ over prolonged periods of time, indicating a similar protective quality of LPFh and LPFo.

Generally, LPF-extended semen reduced variation among the boars, although the individual boar's performance always was the key. This seems to influence sperm motility between extenders within the age groups. Perhaps, pooling semen from these boars could have effectively negated the individual boar-effect. One of the benefits of pooling semen is that it reduces or even climinates inherent differences in fertility found between sperm and between boars (Kuster and Althouse, 1999).

Seasonal influence on sperm motility was more accentuated in semen stored at $5^{\circ} \mathrm{C}$ than that stored at $16^{\circ} \mathrm{C}$ (Table 4). Irrespective of the scasonal periods, deterioration in motility was less marked $(\mathrm{P} \leq 0.05)$ in semen diluted with $\mathrm{K} 3$ LPFh or K3-LPFo extender compared with that of K3 extender on D1-D3 and $\mathrm{D} 1$ of storage at $5^{\circ}$ and $16^{\circ} \mathrm{C}$, respectively. Marked seasonal influence on sperm motility of K3-LPFo-extended semen on D2-D3 at $5^{\circ} \mathrm{C}$ was observed. Furthermore, individual variations among the boars might have influenced sperm motility when comparing the extenders within the seasonal periods. It was reported that the season influenced the fertilizing capacity of liquid stored semen of boars (Sławeta and Strzeżek, 1984).

The changes that occur in boar spermatozoa during liquid storage at different temperatures resemble a natural aging process and may be determined by the conditions and length of storage. It is important to realize that a decline in fertility occurs regardless of whether the sperm are stored at $5^{\circ}$ or $18^{\circ} \mathrm{C}$. Boar sperm subjected to lower temperatures acquire a gradual resistance to cold shock (Pursel et al., 1972). However, the changes in the stored sperm cells that render them resistant to cold shock are not entirely known. The severity of the effect of cold shock is dependent on the rate of cooling, the temperature interval and the temperature range, being generally most severe in the range of $2-12^{\circ} \mathrm{C}$ (Watson, 1995). Cold shock is probably related to the phase transition of membrane lipids, which results in phase separation and loss of selective permeability (Strzezck, 1996). After the addition of egg-yolk lipoprotein fractions to $\mathrm{K} 3$ extender the effects of cold shock were less distinct and the motility decrease at $5^{\circ} \mathrm{C}$ was delayed. The LPF extracted from hen egg yolk protected the spem plasma membrane against deterioration during licuid storage (Demianowicz and Strzezeek, 1996). Our results indicate that the LPF extracted from ostrich egg yolk also protects the spermatozoa against cold shock and improves motility after storage. In the present study both LPFh and LPFo slowed down the storage-dependent aging processes, even though they are somewhat different in terms of their fatty acid and phospholipid composition (Strzezek, 2002). Field trials are in progress to find out whether the changes in sperm motility in K3-LPFh and K3-LPFo extended semen are reflected in fertility results after AI. 


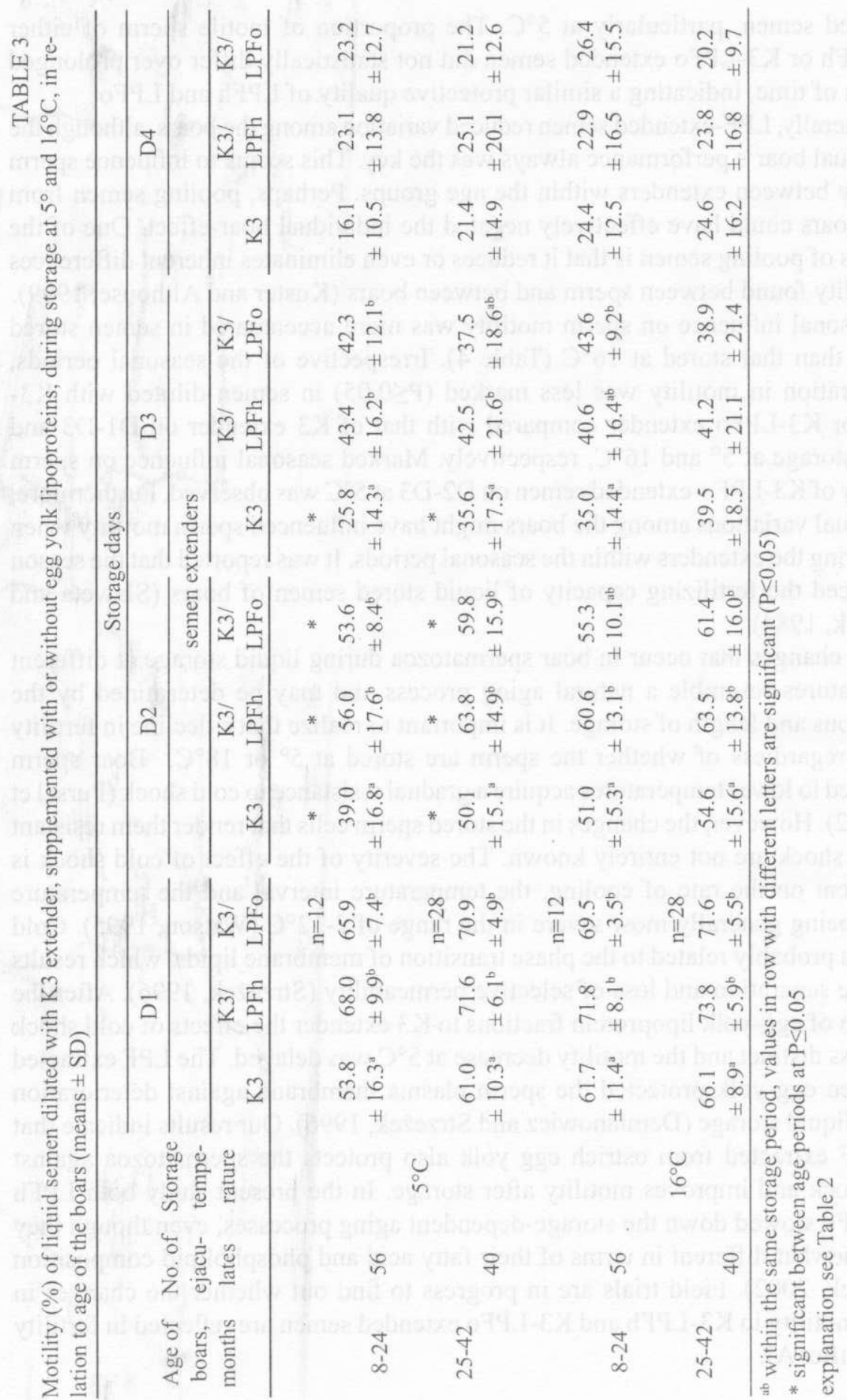




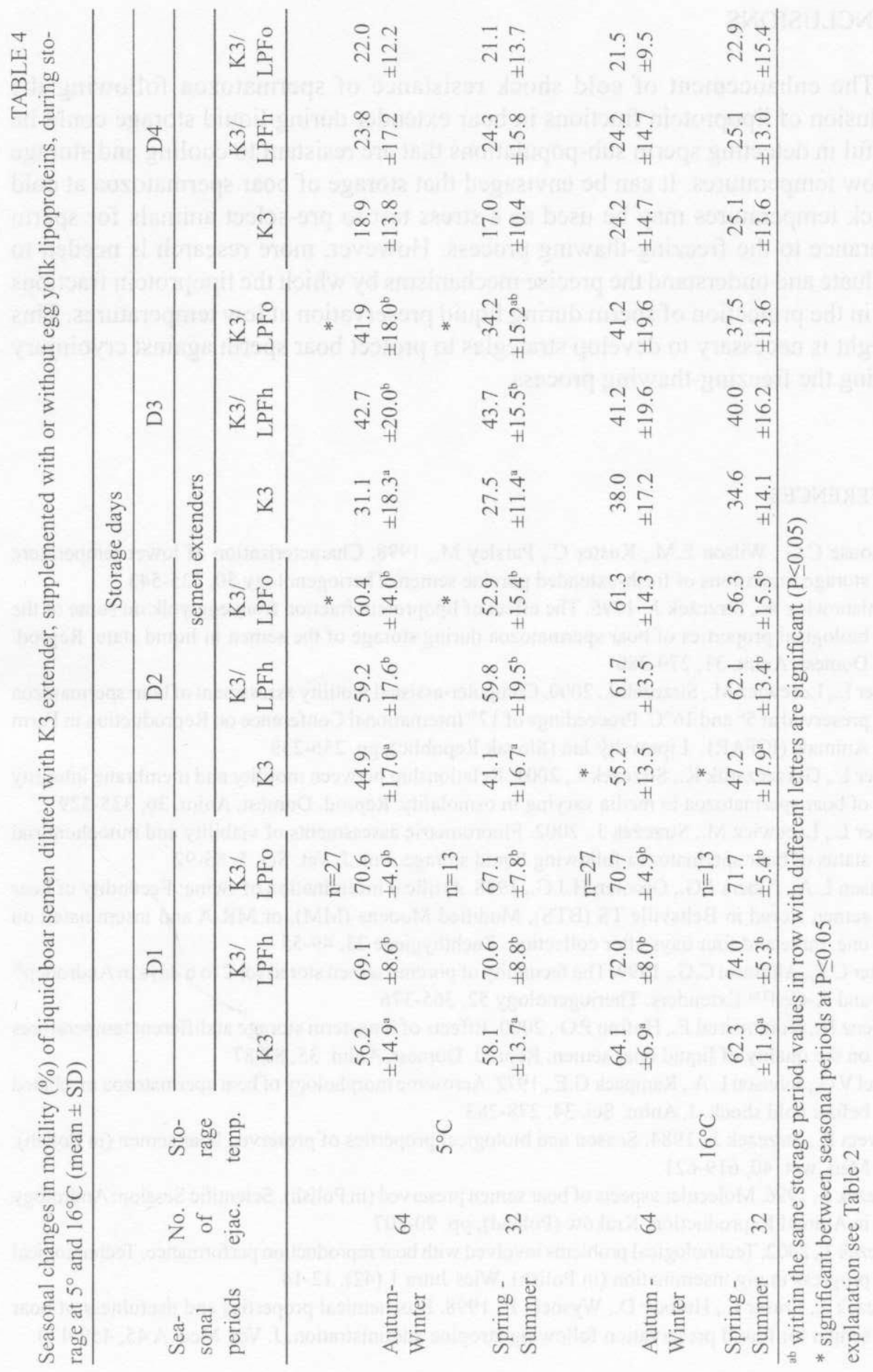




\section{CONCLUSIONS}

The enhancement of cold shock resistance of spermatozoa following the inclusion of lipoprotein fractions in boar extender during liquid storage could be useful in detecting sperm sub-populations that are resistant to cooling and storage at low temperatures. It can be envisaged that storage of boar spermatozoa at cold shock temperatures may be used as a stress test to pre-select animals for sperm tolerance to the freezing-thawing process. However, more research is needed to evaluate and understand the precise mechanisms by which the lipoprotein fractions aid in the protection of sperm during liquid preservation at low temperatures. This insight is necessary to develop strategies to protect boar sperm against cryoinjury during the freezing-thawing process.

\section{REFERENCES}

Althouse C.G., Wilson E.M., Kuster C., Parsley M., 1998. Characterization of lower temperature storage limitations of fresh-extended porcine semen. Theriogenology 50, 535-543

Demianowicz W., Strzeżek J., 1996. The effect of lipoprotein fraction from egg yolk on some of the biological properties of boar spermatozoa during storage of the semen in liquid state. Reprod. Domest. Anim. 31, 279-280

Fraser L., Lecewicz M., Strzeżek J., 2000. Computer-assisted motility assessment of boar spermatozoa preserved at $5^{\circ}$ and $16^{\circ} \mathrm{C}$. Proceedings of $17^{\text {th }}$ International Conference on Reproduction in Farm Animals (ICFAR). Liptovskỳ Jań (Slovak Republic), pp. 236-239

Fraser L., Gorszczaruk K., Strzeżek J., 2001. Relationship between motility and membrane integrity of boar spermatozoa in media varying in osmolality. Reprod. Domest. Anim. 36, 325-329

Fraser L., Lecewicz M., Strzeżek J., 2002. Fluorometric assessments of viability and mitochondrial status of boar spermatozoa following liquid storage. Pol. J. Vet. Sci. 5, 85-92

Johnson L.A., Albers J.G., Grooten H.J.G., 1988. Artifical insemination of swine: Fecundity of boar semen stored in Beltsville TS (BTS), Modified Modena (MM), or MR-A and inseminated on one, three and four days after collection. Zuchthygiene 23, 49-55

Kuster C.E., Althouse C.G., 1999. The fecundity of porcine semen stored for 2 to 6 days in Androhep and X-Cell ${ }^{\mathrm{TM}}$ Extenders. Theriogenology 52, 365-376

Paulenz H., Kommisrud E., Hofmo P.O., 2000. Effects of long-term storage at different temperatures on the quality of liquid boar semen. Reprod. Domest. Anim. 35, 83-87

Pursel V.G., Johnson L.A., Rampack G.E., 1972. Acrosome morphology of boar spermatozoa incubated before cold shock. J. Anim. Sci. 34, 278-283

Sławeta R., Strzeżek J., 1984. Season and biological properties of preserved boar semen (in Polish). Med. wet. 40, 619-621

Strzeżek J., 1996. Molecular aspects of boar semen preserved (in Polish). Scientific Session: Andrology in Animal Reproduction. Kraków (Poland), pp. 90-107

Strzeżek J., 2002. Technological problems involved with boar reproduction performance. Technological progress in pig insemination (in Polish). Wieś Jutra 1 (42), 12-14

Strzeżek J., Fraser L., Hołody D., Wysocki P., 1998. Biochemical properties and usefulness of boar semen for liquid preservation following atropine administration. J. Vet. Med. A 45, 459-470 
Strzeżek J., Lecewicz M., Fraser L., 1999. Ostrich egg yolk as a component of an extender for liquid preservation of boar semen at $5^{\circ}$ and $16^{\circ} \mathrm{C}$. Proceedings of the $3 \mathrm{rd}$ Conference of the European Society on Domestic Animal Reproduction (ESDAR). Anger (France), p. 86

Waberski D., Meding S., Dirksen G., Weitze K.F., Leiding C., Hahn R., 1994. Fertility of long-termstored boar semen: Influence of extender (Androhep and Kiev), storage time and plasma droplets in the semen. Anim. Reprod. Sci. 36, 145-151

Watson P.F., 1975. Use of a Giemsa stain to detect changes in acrosomes of frozen ram spermatozoa. Vet. Rec. 97, 12-15

Watson P.F., 1995. Recent developments and concepts in the cryopreservation of spermatozoa and the assessment of their post-thawing function. Reprod. Fert. Develop. 7, 871-891

Weitze K.F., 1991. Long-term storage of extended boar semen. Reprod. Domest. Anim. 26, Suppl. $1,231-253$

\section{STRESZCZENIE}

Wpływ składu rozcieńczalnika i temperatury przechowywania nasienia knura w stanie płynnym na ruchliwość plemników

Ejakulaty uzyskiwano przez 35 miesięcy od 3 knurów rasy pbz, których użytkowanie rozpłodowe rozpoczęto w wieku 8 miesięcy. Zastosowano standardowy rozcieńczalnik Kortowo 3 (K3) i jego warianty z dodatkiem frakcji lipoprotein ekstrahowanych z żółtka jaja kury (K3-LPFh) lub strusia afrykańskiego (K3-LPFo). Bezpośrednio po rozrzedzeniu ejakulatów (końcowa koncentracja plemników $30 \times 10^{6} / \mathrm{cm}^{3}$ ) próby nasienia przechowywano przez 4 dni (D0 do D4), odpowiednio w temperaturze $5^{\circ}$ i $16^{\circ} \mathrm{C}$.

Niezależnie od rodzaju rozcieńczalnika i temperatury przechowywania obserwowano stopniowy spadek ruchliwości plemników z upływem czasu konserwacji nasienia. Omawiane zmiany, zależne również od wieku knurów i pory roku, były wyraźniejsze przy zastosowaniu rozcieńczalnika K3 bez dodatku LPF. Stwierdzono wpływ pory roku na parametry ruchliwości plemników konserwowanych w rozcieńczalniku K3-LPFo w temperaturze $5^{\circ} \mathrm{C}$.

Podsumowując stwierdzono, że dodatek LPF do rozcieńczalnika zwiększa oporność plemników na udary chłodowe, zwłaszcza podczas konserwacji nasienia knura w temperaturze $5^{\circ} \mathrm{C}$. 